\title{
Depletion of palatable algae by sea urchins and fishes in a Mediterranean subtidal community
}

\author{
Bernat Hereu ${ }^{1,2, *}$ \\ ${ }^{1}$ Departament d'Ecologia, Facultat de Biologia, Universitat de Barcelona, Diagonal 645, 08028 Barcelona, Spain \\ ${ }^{2}$ Present address: Moss Landing Marine Laboratories, 8272 Moss Landing Road, Moss Landing, California 95039, USA
}

\begin{abstract}
I studied the relative and combined effect of sea urchins and fishes on algal biomass in the Mediterranean Medes Island Marine Reserve, using tethering experiments with palatable algae in large enclosures that contained an orthogonal combination of sea urchins and fishes. Sea urchins contributed most to the decline of algae. The effect of fishes was more moderate, but nevertheless not negligible, as a decrease in algal biomass was also observed in the fish treatments at all sites. Surprisingly, the effects of fishes and sea urchins on algal biomass were not additive: the presence of fishes reduced the impact of sea urchins, and the loss of algal biomass was less in the combined treatments. These results add to the literature showing that drastic depletion of palatable algae can be caused by sea urchins, and highlight the contribution of herbivorous and omnivorous fishes to this process. Furthermore, since sea urchin densities were held constant during the experiment, my results support the concept that omnivorous fishes benefit algae in subtidal communities by altering the behavior of urchins (e.g. by inducing avoidance behavior), thus reducing their effectiveness as grazers.
\end{abstract}

KEY WORDS: Herbivory · Omnivory · Tethering · Algae $\cdot$ Sea urchins $\cdot$ Fishes $\cdot$ Trait-mediated interactions · Trophic cascades

\section{INTRODUCTION}

Herbivores contribute greatly to structuring plant and algal communities in a wide range of habitats (e.g. McNaughton \& Georgiadis 1986). In subtidal marine systems, fishes and sea urchins are the main herbivores and often influence the abundance and composition of algal assemblages (e.g. Lubchenco \& Gaines 1981, Choat 1982, Andrew \& Jones 1990, Ruitton et al. 2000, Sala \& Boudouresque 1997).

The effects of sea urchins on seaweeds are welldocumented phenomena in many types of habitats (e.g. Lawrence 1975, Andrew 1993). At high densities, they are capable of depleting all erect algae, which leads to the appearance of barren areas dominated by calcareous encrusting algae (Lawrence 1975, Tegner et al. 1995, but see Prince 1995 and Day \& Branch 2002). In contrast, the role of fishes in structuring algal communities is still debatable (Jones \& Andrew 1990,
Sala \& Boudouresque 1997, Ruitton et al. 2000). As herbivores, fishes can reduce algal biomass (reviews by Horn 1989 and Hay 1991), but as predators, they can control sea urchin populations by predation, thus reducing herbivore pressure through trophic cascades (e.g. McClanahan \& Sala 1997, Sala et al. 1998).

Functional models based on top-down structuring forces provide predictions of control by alternating trophic levels (i.e. consumers on one trophic level regulate the abundance of prey on the trophic level immediately below and cause an alternating sequence of predator control and release from predation down through to the basal trophic level of primary producers) (Hairston et al. 1960, Oksanen et al. 1981, Carpenter et al. 1987, Menge 1995, McClanahan \& Sala 1997).

Fishes occupy more than one trophic level (herbivorous, carnivorous or omnivorous) and, consequently, their interactions with other components of the trophic web are not simply linear. Heterogeneity within and 
between the various trophic levels, together with other factors such as size-structure heterogeneity or behavior-mediated interactions, can lead to departures from the expectations of alternating-control trophic levels (e.g. Persson 1999, Menge 2000, Trussell et al. 2003). Thus, as predicted by theoretical and empirical evidence, omnivory may dampen trophic cascades because it may simultaneously promote and damage a shared resource through different effects (Diehl 1992, Polis \& Strong 1996).

Experimental determination of the effects of omnivores on trophic webs has been reported in freshwater systems (e.g. Diehl 1992); however, examples for terrestrial and marine systems are still scarce (Pinnegar \& Polunin 2000). In temperate subtidal communities, several studies have addressed the role of fishes in structuring temperate algal communities (Jones \& Andrew 1990, Sala \& Boudouresque 1997, Ruitton et al. 2000). Nevertheless, few have tested the combined effects of herbivorous fishes and sea urchins (but see Ruitton et al. 2000), and no experimental manipulations have been made.

In the Mediterranean Sea, sparid fishes are the main predators of adult sea urchins; they are simultaneously herbivores (Sala \& Zabala 1996), thus increasing trophic connections in the food web. To quantify the relative contribution of herbivorous and omnivorous fishes and sea urchins to the depletion of algal biomass, and their combined effects, I performed tethering experiments using large enclosures $\left(>15 \mathrm{~m}^{2}\right)$ with an orthogonal combination of fishes (herbivorous and omnivorous) and sea urchins (herbivorous).

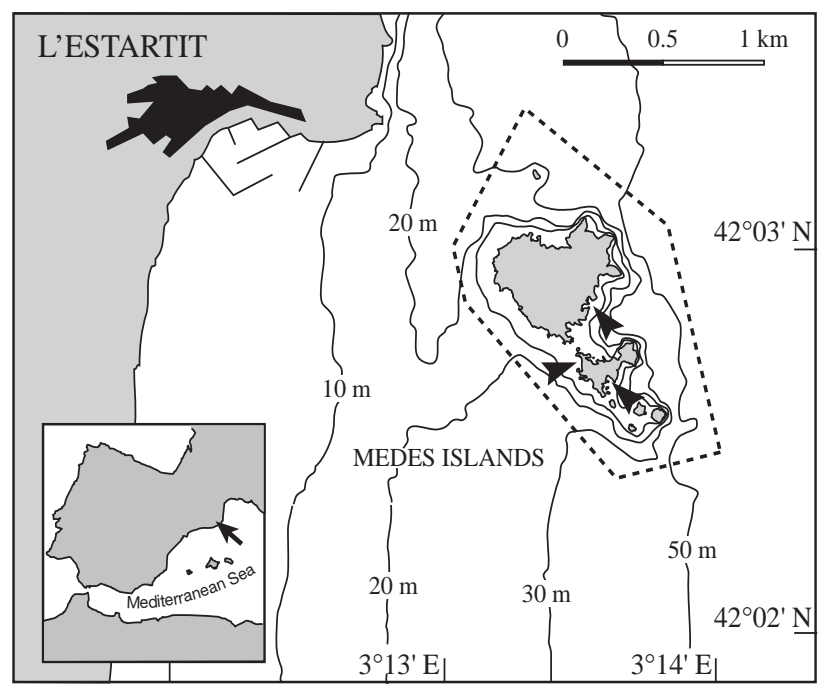

Fig. 1. Location of study sites, inside Medes Islands protected area, NE Spain, NW Mediterranean Sea. Dotted line: limits of Medes Islands Protected Area, where all fishing is prohibited. Arrowheads mark sites where experiments were replicated

\section{MATERIALS AND METHODS}

The study was carried out in Medes Islands Marine Reserve $\left(42^{\circ} 16^{\prime} \mathrm{N}, 03^{\circ} 13^{\prime} \mathrm{E}\right), \mathrm{NW}$ Mediterranean Sea (Fig. 1), where fishing has been prohibited since 1983. I selected 3 sites (Racó del Portitxol, Cova de la Reina and Sant Istiu) with similar orientations (S to SW) and depths (5 to $8 \mathrm{~m}$ ) and a substratum of large rocky boulders.

Fish assemblages at the study sites are described in Garcia-Rubies \& Zabala (1990), Garcia-Rubies (1999) and in Hereu (2004); diet and grazing impacts are reported in Sala \& Ballesteros (1997) and Sala \& Boudouresque (1997). As a result of the prohibition of fishing activities, the densities and sizes of fishes populations around the Medes Islands are among the highest in the Mediterranean, despite some spatial variability (Table 1). The main and most abundant benthic-feeding fishes are omnivorous sparids, mainly Diplodus spp., and small labrids, mainly Coris julis, which are carnivorous; the only truely herbivorous fish, Sarpa salpa (Linnaeus, 1758), is also present in high abundance (Table 1) in the region.

Experimental design. To determine the relative impact of fish and sea urchin grazing on algal assemblages, grazer exclusion experiments were performed over 4 wk in July 1999.

I manipulated herbivorous and omnivorous fishes and the sea urchin Paracentrotus lividus (de Lamarck, 1816), the most abundant urchin in the region (Sala \& Zabala, 1996, Hereu 2004). Grazing exclusion was replicated at the 3 experimental sites (Racó del Portitxol, Cova de la Reina and Sant Istiu) (Fig. 1). The experiment consisted of orthogonal combinations of the presence/absence of each group. I established 4 groups: no grazers (C), sea urchins only (U), fishes only (F), sea urchins and fishes (FU) (Fig. 2).

Table 1. Mean $( \pm \mathrm{SE})$ abundance of several main fish species (no. of individuals $250 \mathrm{~m}^{-2}$ ) in 2 zones of the Medes Islands Marine Reserve (from Garcia-Rubies \& Zabala 1990)

\begin{tabular}{|lcc|}
\hline Species & Tascons & Freuetó \\
\hline Scorpaena porcus L. & $1.8 \pm 0.9$ & $1.4 \pm 0.7$ \\
Serranus cabrilla (L.) & $9.6 \pm 0.5$ & $12.0 \pm 1.3$ \\
Diplodus sargus (L.) & $105.6 \pm 13.6$ & $14.4 \pm 3.6$ \\
Diplodus vulgaris (E. G. Sain-Hilaire) & $24.8 \pm 2.3$ & $7.2 \pm 1.3$ \\
Diplodus cervinus (Lowe) & $2.8 \pm 0.7$ & $0.8 \pm 0.5$ \\
Diplodus annularis L. & $1.4 \pm 0.2$ & $1.0 \pm 0.3$ \\
Diplodus puntazzo (Cetti) & $8.0 \pm 4.4$ & $1.6 \pm 0.4$ \\
Sparus aurata L. & $11.4 \pm 1.4$ & $1.2 \pm 0.9$ \\
Sarpa salpa (L.) & $71.6 \pm 41.4$ & $11.6 \pm 4.74$ \\
Sciaena umbra L. & $12.8 \pm 8.3$ & $4.2 \pm 1.3$ \\
Symphodus tinca (L.) & $8.2 \pm 1.6$ & $3.6 \pm 1.9$ \\
Symphodus mediterraneus (L.) & $7.2 \pm 1.0$ & $6.0 \pm 1.1$ \\
Coris julis (L.) & $51.2 \pm 5.1$ & $36.8 \pm 7.4$ \\
\end{tabular}




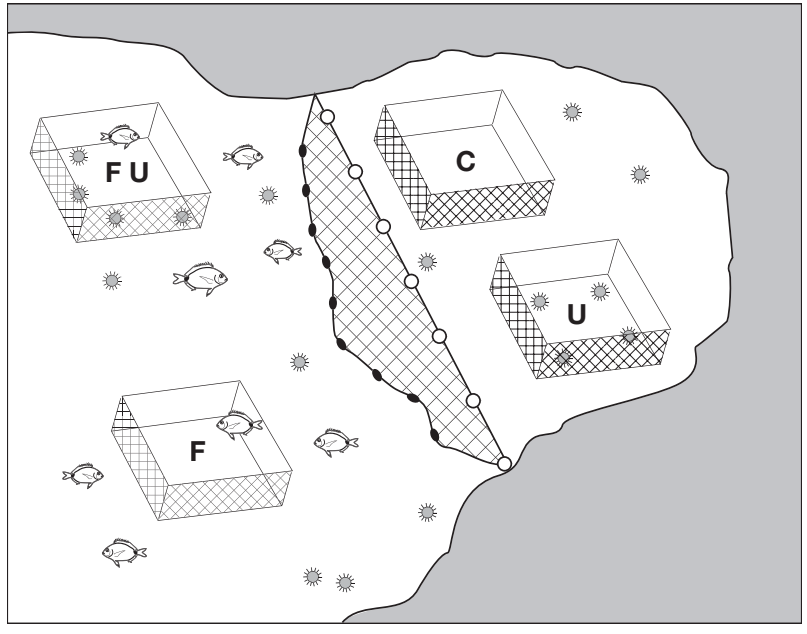

Fig. 2. Schematic design of 1 set of experimental enclosures in which presence/absence of fishes and sea urchins were orthogonally controlled, allowing combinations of sea urchin and fish presence for treatments (C: no herbivores; U: only sea urchins; F: only fishes; FU: sea urchins plus fishes). Trawler net closing off small cove is also shown

Fish exclusion treatments were achieved by closing off small coves (70 to $110 \mathrm{~m}^{2}$ ) with nets. Polypropylene trawler nets of $2.5 \mathrm{~cm}$ mesh size, 6 to $8 \mathrm{~m}$ depth and 11 to $16 \mathrm{~m}$ length were attached to a steel cable anchored in the substratum with autoexpansive nails. The upper part of the net was continuously kept on the surface by plastic buoys. The exclusion nets were cleaned and checked daily, and replaced every other week to prevent significant fouling. Roofless, herbivore-exclusion nets have negligible light-shading effects (Lewis 1986). Although water flow might have differed inside and outside the small coves, the plot treatments were very close, separated only by the large mesh net, and no great differences in environmental conditions between plots were expected. Furthermore, in a parallel study of natural algal communities using the same installations, no differences between plots were found in the initial control (Hereu 2004).

Although increased densities of micrograzers are a potential confounding factor in the interpretation of experimental manipulations involving caging treatments (Dayton \& Oliver 1980), the size of the exclosures used in the present experiment diminished the likelihood of artifacts usually associated with small cages. The net mesh size used allowed free passage to juvenile sparids and several small labrids that are carnivores. Thus, the abundant Coris julis and other small wrasses such as Symphodus ocellatus, S. roissali or Thalassoma pavo, predators of gastropods, small crustaceans and juvenile echinoderms $(0.2$ to $1 \mathrm{~cm})$ (Sala \& Zabala 1996, Hereu et al. 2005), moved freely through the enclosed areas and were commonly observed feed- ing within them. The experiment thus tested the effects of adult herbivorous (mainly Sarpa salpa) and adult omnivorous (mainly Diplodus sargus, D. vulgaris, D. puntazzo), and largest carnivorous (e.g. Labrus merula or Symphodus tinca) fishes only.

To remove large fishes from each enclosure at the beginning of the experiment, the net was tied to the plastic buoys at the surface, and several divers scared the fishes away from the cove. The net was then let down to the bottom and attached to the steel cable, thus isolating the entire cove from large herbivorous and omnivorous fishes.

For the treatments with and without sea urchins, $16 \mathrm{~m}^{2}$ enclosures were built in and outside the exclusion coves using $10 \mathrm{~cm}$ tall plastic fences (mesh size $2 \mathrm{~cm}$ ) supported by steel rods anchored in the substratum. Because algal assemblages were not sampled near the edges of the enclosures and these fences did not interfere with light and water movement (Sala \& Boudouresque 1997), I assumed that caging artifacts were negligible. For the treatments without sea urchins, all urchins from several large boulders in and outside the coves, which were also enclosed by plastic fences, were removed (Fig. 2). To ensure that there were no reinvasions in urchin-free treatments or escape of sea urchins from inclusion treatments, weekly observations were made inside and around the plots, and densities were replenished when necessary. Sea urchin densities similar to those before the experiment ( 9 to 14 urchins $\mathrm{m}^{-2}$ ) and with similar size distributions were established and maintained in the sea urchin enclosure throughout the study. These enclosures were checked daily and new sea urchins were added when predation by fishes was detected.

The abundance and size of herbivorous and omnivorous fishes were determined by 4 replicate censuses per site and treatment (inside and outside enclosures). Each census was performed by standing at a fixed point and counting all fishes in an area of $50 \mathrm{~m}^{2}$, and fish biomass was estimated using length-mass equations (Bayle et al. 2001).

Experiments were performed with Cystoseira sp. and Padina pavonica (Linnaeus) Thivy because these are the most abundant palatable algae during summer (Sala \& Boudouresque 1997) and they occur in the vicinity of the grazing trials at all the study sites. It was assumed that the rates of algal consumption measured were not confounded by among-habitat in differences background availability of these plant species. Cystoseira sp. has not been clearly identified. Sala \& Boudouresque (1997) identified it as C. spinosa Savaugeau, but recent studies identified it as C. elegans Sauvageau (B. Hereu unpubl. data).

Consumption rates of the 2 algae were measured with a standardized assay for herbivorous fish grazing, 
modified from Hay (1981) and Lewis (1986). Algae were collected whole by a hammer and chisel. Fleshy algae were spun-dry for $1 \mathrm{~min}$ and weighed to the nearest $0.1 \mathrm{~g}$. I attached 9 randomly disposed thalli (4 of each of the 2 species plus an extra thallus) with a nylon line to plastic mesh holders fixed to a ceramic plate measuring $40 \times 20 \times 0.5 \mathrm{~cm} ; 5$ plates were placed randomly on the bottom of each of the 4 enclosures at each site, thereby permitting access to fishes and sea urchins. Thus, at least 20 thalli from each species per treatment per site were installed $(\mathrm{n}=480)$.

During the experiment, algal height was measured weekly with a ruler. At the end of the experiment, the plants were removed and reweighed, and the differences between initial and final weights were compared. To avoid confusing the effects of grazing with accidental losses, thalli that disappeared were not included in the analysis.

Data analysis. To determine the effect of the different treatments on algal height, we conducted a 2-way repeated-measures analysis of variance (RMANOVA; von Ende 1993) for each species. Treatments (C, U, F, $\mathrm{FU}$ ) as fixed factor and site as random factor were the between-subject factors, and time (i.e. sampling events $\mathrm{T} 0, \mathrm{~T} 1, \mathrm{~T} 2, \mathrm{~T} 3$ and T4) the repeated-measures (withinsubject) factor. To test whether the data matrix fulfilled circularity, we used Mauchly's test of sphericity. When sphericity was violated, we made a Huynh-Feldt adjustment by multiplying the numerator and denominator degrees of freedom by epsilon $(\varepsilon$ ) (von Ende 1993), after which $F$-values and probabilities were calculated. A Student-Newman-Keuls (SNK) post-hoc test was performed for each sampling time to interpret the interaction between treatments, and on each treatment to interpret the progress of the experiment (Underwood 1997).

The weight increase (or decrease) standardized to percentage initial weight during the experiments (final -initial/initial wet weight) was used to test the biomass increment (increase by growth-decrease by herbivory) for each species. The effects of the distinct treatments as fixed factors, and site as random factor, were tested by 2-way ANOVA. To interpret the interaction between treatments, an SNK post-hoc test was performed (Underwood 1997).

\section{RESULTS}

A total of 46 fish species were observed at the stations. For simplicity, I here present the results for the main herbivorous fish Sarpa salpa and the omnivorous Diplodus sargus (Linnaeus, 1758) only. These fishes did not show differences in biomass between sites, but
Table 2. Diplodus sargus and Sarpa salpa. Results of 2-way ANOVA testing differences in biomass between enclosed and control treatments (fixed factor) and between sites (random factor) in July 1999.

Data were $\log (x+1)$-transformed to avoid heteroscedasticity

\begin{tabular}{|lrrrrrr|}
\hline & df & MS & \multicolumn{2}{c}{ Error } & \multirow{2}{*}{$F$} & $\mathrm{p}$ \\
& & & df & MS & & \\
\hline Diplodus sargus & & & & & & \\
$\quad$ Site & 2 & 0.12 & 18 & 0.38 & 0.32 & 0.725 \\
$\quad$ Treatment & 1 & 33.38 & 2 & 0.22 & 147.65 & $\mathbf{0 . 0 0 7}$ \\
$\quad$ Site $\times$ Treatment & 2 & 0.22 & 18 & 0.38 & 0.60 & 0.560 \\
Sarpa salpa & & & & & & \\
$\quad$ Site & 2 & 0.37 & 18 & 0.26 & 1.46 & 0.258 \\
$\quad$ Treatment & 1 & 26.47 & 2 & 0.02 & 1305.50 & $\mathbf{0 . 0 0 1}$ \\
Site $\times$ Treatment & 2 & 0.02 & 18 & 0.26 & 0.08 & 0.925 \\
\hline
\end{tabular}

significant differences between enclosed and nonenclosed sites were observed (Table 2 \& Fig. 3).

Small labrids such as Coris julis, Thalasoma pavo, Symphodus ocellatus, S. mediterraneus and S. tinca were observed swimming freely inside the exclosures, and even feeding from the benthos. Nevertheless, no attacks on sea urchins were observed inside exclosures, probably because the urchins were too large to be eaten by such small fishes (Hereu et al. 2005). Outside the exclosures, no direct observations were made; nevertheless, some loss of sea urchins was observed, which could have been due to predation, and sea urchins sheltered more in crevices and substrata folds, whereas inside the exclosures they moved freely.

Several visual observations and photographs of herbivorous and omnivorous fishes and sea urchins eating

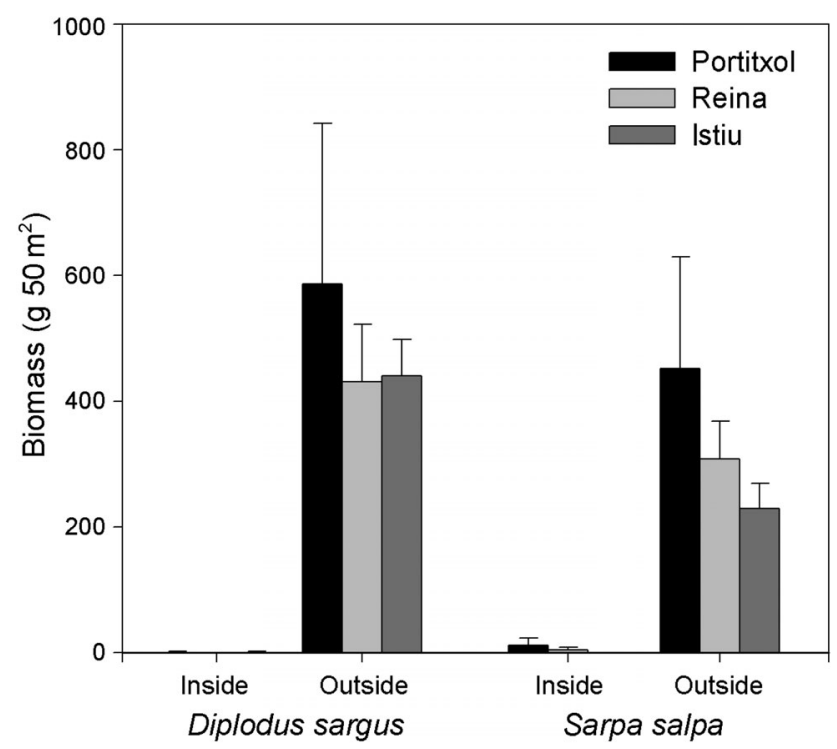

Fig. 3. Diplodus sargus and Sarpa salpa. Mean $( \pm \mathrm{SE})$ biomass inside and outside fish exclusion treatments at each experimental site in July 1999 
transplanted algae were made during the experiment (see photographs in Hereu 2004). Sea urchins overran the plates, depleting the whole thalli they encountered and leaving only the bases of the algae attached to the nylon line. In contrast, fishes bit only the apical part of the algae, leaving the rest of the plant intact.

In all experiments, treatments had a clear influence on algal height and weight (Figs. 4 \& 5). Height increment analysis of Padina pavonica and Cystoseira sp. revealed similar patterns (Tables $3 \& 4$ ). There was a significant interaction between time and treatment and site, indicating that, as the experiment advanced, differences between treatments became more evident and that the evolution of the treatments differed as a function of site, even though the final results were similar.

The results of the post-hoc test showed that treatments with herbivores reduced algal height, while in herbivore exclusion plots the algal height remained constant or even increased. Furthermore, while sea urchins reduced algae height, the pattern was more moderate when fishes and sea urchins occurred together. At the end of the experiment, height in the U

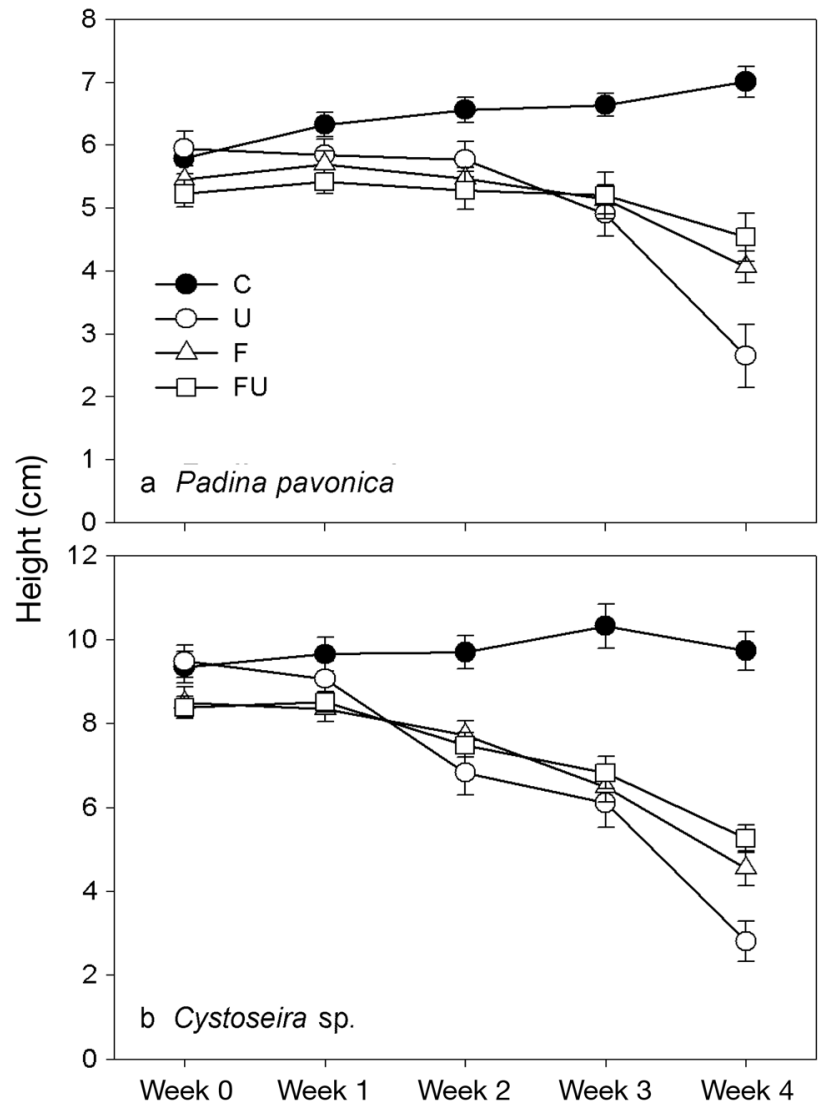

Fig. 4. Padina pavonica and Cystoseira sp. (a) P. pavonica $(\mathrm{n}=207)$; (b) Cystoseira sp. $(\mathrm{n}=199)$. Mean $( \pm$ SE) height increments of transplanted algae in each treatment during the 4 wk study period in July 1999. Abbreviations as in Fig. 2 treatments was lower than in $\mathrm{F}$ and FU for both algae (Fig. 4, Tables 3 \& 4). In the case of Padona pavonica, height differences in the $F$ and $U$ treatments were significant until the last week of the experiment, in the $\mathrm{C}$ treatment height increased during the first week, and in the FU treatment it remained constant. Differences in Cystoseira sp. height were evident from the second or the third week for the herbivore treatments, while in the $\mathrm{C}$ treatment heigth remained constant (Tables 3 \& 4).

The weight increments of Padina pavonica and Cystoseira sp. showed patterns similar to height increments. In the herbivore treatment there was a net decrease in weight, while in the herbivore exclusion treatments weight increased (Fig. 5). In both species significant differences between treatments were detected. In the case of Padina pavonica, the weight decrease in the $\mathrm{F}$ and $\mathrm{U}$ treatments was higher than in the FU treatment, while in the $\mathrm{C}$ treatment there was a net increase in weight. Cystoseira sp. weight in the U plots decreased more than in the F and FU plots, while in the $\mathrm{C}$ plots there was a net increase (Fig. 5 \& Table 5).

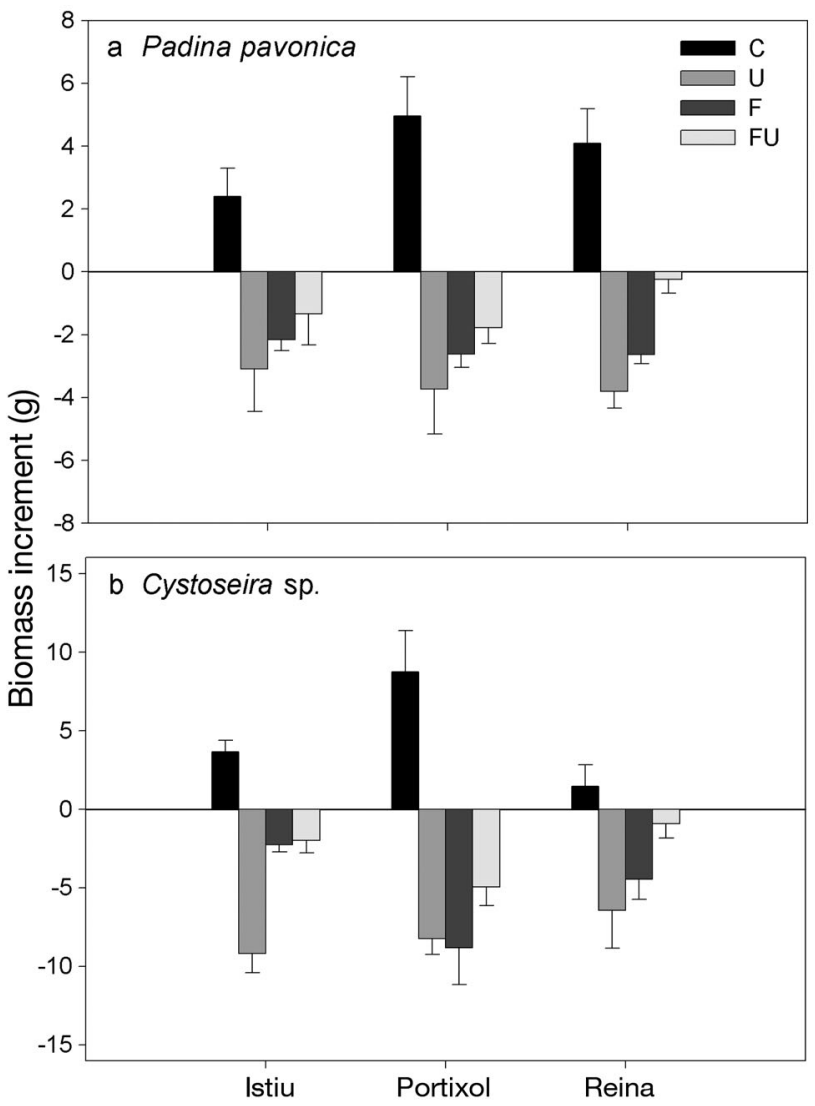

Fig. 5. Padina pavonica and Cystoseira sp. (a) P. pavonica $(\mathrm{n}=207)$; (b) Cystoseira sp. $(\mathrm{n}=199)$ Mean $( \pm \mathrm{SE})$ biomass increments of transplanted algae in each treatment at each site in July 1999. Abbreviations as in Fig. 2 
In the experiments with Cystoseira sp. an interaction between treatment and site was observed. These differences (and those in the height analyses) were probably caused by the different environmental conditions at the sampling sites, which could affect algal growth, and also by local differences in herbivorous fish densities.

Table 3. Padina pavonica. Repeated-measures ANOVA of impact of herbivores on algal height in Medes Island Marine Reserve in July 1999. Bold values indicate significant differences. Treatment variances were homogeneous and levels of the repeated-measures factor are independent (sphericity test, $W=0.37 ; \mathrm{p}=0.00 ; \mathrm{df}=9$ ). Huynh-Feldt corrected probabilities ( $\mathrm{p} \mathrm{H}-\mathrm{F}$ ) are given for both the between-subject and within-subject analyses $(\mathrm{H}-\mathrm{F}$ epsilon $=0.73)$. In SNK post-hoc analysis, Treatment $\mathrm{C}=-$ fishes, - urchins; $\mathrm{F}=$ +fishes, -urchins; $\mathrm{U}=$-fishes, +urchins; $\mathrm{FU}=$ +fishes, +urchins

\begin{tabular}{|c|c|c|c|c|c|c|}
\hline \multirow[t]{2}{*}{ Source } & \multirow[t]{2}{*}{ df } & \multirow[t]{2}{*}{ MS } & \multicolumn{2}{|c|}{ Error } & \multirow[t]{2}{*}{$F$} & \multirow[t]{2}{*}{$\mathrm{p}$} \\
\hline & & & df & MS & & \\
\hline \multicolumn{7}{|l|}{ Between subjects } \\
\hline Site (S) & 2 & 68.46 & 195 & 9.07 & 7.55 & 0.001 \\
\hline Treatment $(\mathrm{H})$ & 3 & 117.87 & 6 & 24.11 & 4.89 & 0.047 \\
\hline $\mathrm{H} \times \mathrm{S}$ & 6 & 24.11 & 195 & 9.07 & 2.66 & 0.017 \\
\hline \multicolumn{7}{|l|}{ Within subjects } \\
\hline Time $(\mathrm{T})$ & 4 & 53.98 & 8 & 11.69 & 4.62 & 0.032 \\
\hline $\mathrm{T} \times \mathrm{S}$ & 8 & 11.69 & 780 & 2.07 & 5.64 & $<0.000$ \\
\hline $\mathrm{T} \times \mathrm{H}$ & 12 & 27.89 & 24 & 5.23 & 5.33 & $<0.000$ \\
\hline $\mathrm{T} \times \mathrm{H} \times \mathrm{S}$ & 24 & 5.23 & 780 & 2.07 & 2.52 & $<0.000$ \\
\hline \multicolumn{7}{|c|}{ SNK post-hoc comparison } \\
\hline \multicolumn{7}{|c|}{ Treatments $\quad$ Time } \\
\hline \multicolumn{2}{|l|}{ T0: $\mathrm{C}=\mathrm{F}=\mathrm{FU}=\mathrm{U}$} & \multicolumn{5}{|c|}{$\mathrm{C}: \mathrm{T} 0=\mathrm{T} 1=\mathrm{T} 2=\mathrm{T} 3=\mathrm{T} 4$} \\
\hline \multicolumn{2}{|l|}{$\mathrm{T} 1: \mathrm{C}=\mathrm{F}=\mathrm{FU}=\mathrm{U}$} & \multicolumn{5}{|c|}{$\mathrm{F}: \quad \mathrm{T} 0=\mathrm{T} 1>\mathrm{T} 2=\mathrm{T} 3>\mathrm{T} 4$} \\
\hline \multicolumn{2}{|l|}{$\mathrm{T} 2: \mathrm{C}>\mathrm{U}=\mathrm{FU}=\mathrm{U}$} & \multicolumn{5}{|c|}{$\mathrm{U}: \mathrm{T} 0=\mathrm{T} 1=\mathrm{T} 2>\mathrm{T} 3>\mathrm{T} 4$} \\
\hline \multicolumn{2}{|l|}{ T3: $\mathrm{C}>\mathrm{F}=\mathrm{FU}=\mathrm{U}$} & \multicolumn{5}{|c|}{ FU: $\mathrm{T} 0=\mathrm{T} 1>\mathrm{T} 2=\mathrm{T} 3>\mathrm{T} 4$} \\
\hline $\mathrm{T} 4: \mathrm{C}>\mathrm{F}=\mathrm{FU}>\mathrm{U}$ & & & & & & \\
\hline
\end{tabular}

Table 4. Cystoseira sp. Repeated-measures ANOVA of impact of fishes and sea urchins on algal height in Medes Island Marine Reserve in July 1999. Further details as in Table 3 (sphericity test, $W=0.38 ; \mathrm{p}=0.00 ; \mathrm{df}=9) ;(\mathrm{H}-\mathrm{F}$ epsilon $=0.77)$

\begin{tabular}{|c|c|c|c|c|c|c|}
\hline \multirow[t]{2}{*}{ Source } & \multirow[t]{2}{*}{$\mathrm{df}$} & \multirow[t]{2}{*}{ MS } & \multicolumn{2}{|c|}{ Error } & \multirow[t]{2}{*}{$F$} & \multirow[t]{2}{*}{$\mathrm{p}$} \\
\hline & & & df & MS & & \\
\hline \multicolumn{7}{|l|}{ Between subjects } \\
\hline Site (S) & 2 & 34.55 & 187 & 21.76 & 1.59 & 0.207 \\
\hline Treatment $(\mathrm{H})$ & 3 & 458.51 & 6 & 95.86 & 4.78 & 0.049 \\
\hline $\mathrm{H} \times \mathrm{S}$ & 6 & 95.86 & 187 & 21.76 & 4.40 & $<0.000$ \\
\hline \multicolumn{7}{|l|}{ Within subjects } \\
\hline Time (T) & 4 & 387.08 & 8 & 25.50 & 15.18 & $<0.001$ \\
\hline $\mathrm{T} \times \mathrm{S}$ & 8 & 25.50 & 748 & 3.61 & 7.06 & $<0.000$ \\
\hline $\mathrm{T} \times \mathrm{H}$ & 12 & 76.23 & 24 & 17.57 & 4.34 & 0.001 \\
\hline $\mathrm{T} \times \mathrm{H} \times \mathrm{S}$ & 24 & 17.57 & 748 & 3.61 & 4.87 & $<0.000$ \\
\hline \multicolumn{7}{|c|}{ SNK post-hoc comparison } \\
\hline \multicolumn{7}{|c|}{ Treatments } \\
\hline \multicolumn{2}{|c|}{ T0: $\mathrm{C}=\mathrm{F}=\mathrm{FU}=\mathrm{U}$} & \multicolumn{4}{|c|}{$\mathrm{C}: \quad \mathrm{T} 0=\mathrm{T} 1=\mathrm{T} 2=\mathrm{T} 3=\mathrm{T} 4$} & \\
\hline \multicolumn{2}{|c|}{$\mathrm{T} 1: \mathrm{C}=\mathrm{F}=\mathrm{FU}=\mathrm{U}$} & \multirow{2}{*}{\multicolumn{4}{|c|}{$\mathrm{F}: \quad \mathrm{T} 0=\mathrm{T} 1>\mathrm{T} 2=\mathrm{T} 3>\mathrm{T} 4$}} & \\
\hline \multicolumn{2}{|c|}{ T2: $\mathrm{C}>\mathrm{U}=\mathrm{FU}=\mathrm{U}$} & \multirow{2}{*}{\multicolumn{4}{|c|}{$\mathrm{U}: \quad \mathrm{T} 0=\mathrm{T} 1=\mathrm{T} 2>\mathrm{T} 3>\mathrm{T} 4$}} & \\
\hline \multicolumn{2}{|c|}{ T3: $\mathrm{C}>\mathrm{F}=\mathrm{FU}=\mathrm{U}$} & & & & & \\
\hline $\mathrm{T} 4: \mathrm{C}>\mathrm{F}=\mathrm{FU}>$ & & \multicolumn{4}{|c|}{ FU: $\mathrm{T} 0=\mathrm{T} 1>\mathrm{T} 2=\mathrm{T} 3>\mathrm{T} 4$} & \\
\hline
\end{tabular}

\section{DISCUSSION}

The effect of herbivorous fishes on algae in temperate seas, and particularly in the Mediterranean, is a much debated issue (e.g. Sala \& Boudouresque 1997, Sala et al. 1998, Ruitton et al. 2000). While sea urchins are often considered major grazers in infralittoral temperate communities, herbivorous fishes are generally considered browsers of minor importance (e.g. Choat 1982, Horn 1989, but see Jones \& Andrew 1990). However, recent studies in the Mediterranean have shown the large contribution of herbivorous fishes to structuring infralittoral algal communities (Verlaque 1990, Sala \& Boudouresque 1997, Ruitton et al. 2000).

In addition, most studies on herbivory have addressed fishes and sea urchins separately. Given that fishes and sea urchins share habitats, their interaction could lead to responses that are not detected by experiments dealing with them individually. My experimental design allowed the study of the effect of sea urchins and fishes separately and combined on 2 palatable algae species under natural conditions. Although speciesspecific relationships do not reflect the whole community pattern, the algae tethering experiments allowed me to quantify biomass increments rather than simply recording the percentage of algal cover.

Large enclosures comprised of roofless nets closing off small coves allowed algal transplants in optimal conditions. At all sites, all algal thalli in herbivore exclusion treatments showed a significant increase in height and weight. On the basis of this observation, I concluded that there were no serious artefacts caused by manipulation while transplanting the algae. Given the short life cycle of these seasonal algae, 4 wk was sufficiently long to test the effects of herbivory. Furthermore, in the $4 \mathrm{wk}$ period, $50 \%$ of transplanted algae in the $U$ treatment were totally depleted (only the bases of the thalli attached to the nylon line remained): in a longer experiment, the results would be more pronounced because the number of completely depleted algae in this treatment would increase.

The greatest effect on algal decline was in the $U$ treatments, where all algal thalli decreased significantly. Grazing by Paracentrotus lividus is characterized by the removal of whole plants, including their bases, a process described as 'bulldozing' (Verlaque 1984). Thus, thalli grazed by sea urchins were almost entirely depleted and only a small base attached to the nylon line remained in the plastic mesh holders. 
Table 5. Padina pavonica and Cystoseira sp. Results of ANOVA comparing weight increments of algae between fish and urchin treatments and site. Bold values indicate significant differences.

Abbreviations as in Table 3

\begin{tabular}{|c|c|c|c|c|c|c|}
\hline \multirow[t]{2}{*}{ Factor } & \multirow{2}{*}{ df } & \multirow[t]{2}{*}{ MS } & \multicolumn{2}{|c|}{ Error } & \multirow[t]{2}{*}{$F$} & \multirow[t]{2}{*}{$\mathrm{p}$} \\
\hline & & & df & MS & & \\
\hline \multicolumn{7}{|l|}{ Padina pavonica } \\
\hline Site (S) & 2 & 0.19 & 195 & 0.71 & 0.27 & 0.757 \\
\hline Treatment $(\mathrm{H})$ & 3 & 35.80 & 6 & 0.49 & 72.10 & $<0.000$ \\
\hline $\mathrm{H} \times \mathrm{S}$ & 6 & 0.49 & 195 & 0.71 & 0.69 & 0.650 \\
\hline \multicolumn{7}{|c|}{ SNK post-hoc test: $\mathrm{C}>\mathrm{FU}>\mathrm{F}=\mathrm{U}$} \\
\hline \multicolumn{7}{|l|}{ Cystoseira sp. } \\
\hline Site (S) & 2 & 0.07 & 187 & 0.25 & 0.275 & 0.756 \\
\hline Treatment $(\mathrm{H})$ & 3 & 12.88 & 6 & 1.52 & 8.42 & 0.014 \\
\hline $\mathrm{H} \times \mathrm{S}$ & 6 & 1.52 & 187 & 0.25 & 6.10 & $<0.000$ \\
\hline
\end{tabular}

The effects of fishes were more moderate, but nevertheless greater than expected, and were detected as net differences between treatments at all sites. In contrast to sea urchins, fishes did not deplete whole thalli, but reduced only the apical parts of the algae. These differences are the result of different feeding behavior: fishes bite but do not graze, and therefore algal growth can continue. Although the effects of fishes on algal assemblages were not as great as those of sea urchins, my results indicate that herbivorous fishes can affect the biomass of palatable algae.

Although these results are consistent with the effects of herbivorous fishes on seaweed reported elsewhere (Verlaque 1990, Sala \& Boudouresque 1997, Ruitton et al. 2000), they should be interpreted with care, since here I tested the effects of herbivory on only 2 palatable algae species. Like most trophic cascade experiments, strong interactions can occur between pairs of species, while at the level of the entire community the effects of herbivory may be quite different (Kennelly 1991, Polis \& Strong 1996, but see Anderson 1999). Furthermore, this experiment was performed during the summer, when most algal growth is limited (Ballesteros 1991). Similar experiments during spring show a less clear effect of herbivores, probably because algal production is maximal during this season (Ballesteros 1991) and there is a major availability of other palatable algae. In a parallel long-term study on natural communities, I also observed a modulation of the herbivore effects during the season of highest algal growth (Hereu 2004).

Sala \& Ballesteros (1997) and Sala \& Boudouresque (1997) suggested that herbivorous fishes are selective and prefer a range of palatable species, including Padina pavonica and Cystoseira spp. In the present study, which tethered specifically palatable species, there was a clear reduction in algae biomass in the presence of fishes. In a parallel study, herbivorous fishes had no clear effect at the level of the entire algal community, since partial analysis of individual species showed variable responses, and total algal cover did not differ in the presence or absence of fishes (Hereu 2004), probably through compensatory growth of less palatable species (Sala \& Boudouresque 1997).

Surprisingly, the depletive effects of fishes and sea urchins on algal biomass were not additive. This may have been due to the effect of omnivorous fishes such as Diplodus vulgaris. This species is not only abundant at the study sites, but also depletes palatable algae and is the main sea urchin predator (Sala \& Zabala 1996). Because of its direct lethal effect on sea urchins as revealed by current trophic models (e.g. Sala \& Zabala 1996, McClanahan \& Sala 1997), this abundant omnivorous sparid could indirectly benefit plants. This mechanism is included in conventional theory on trophic, density-dependent interaction models (i.e. Hairston et al. 1960, Oksanen et al. 1981). Nevertheless, since sea urchin densities were maintained artificially during the present experiments, my results cannot be explained by direct lethal effects of fishes.

Carnivores can also favor algal assemblages indirectly inducing escape responses in herbivores to avoid predation. The escape response of sea urchins in the presence of predators (e.g. Hagen \& Mann 1994, Hereu 2005) could explain these unexpected results. Many investigators consider the nocturnal activity of Paracentrotus lividus to be a means of avoiding diurnal predators (e.g. Hereu 2005, but see Crook et al. 2000). Furthermore, in zones of high fish density, $P$. lividus reduces its foraging range, thus potentially decreasing its grazing effect on algal communities (Hereu 2005). I did not anticipate that fish-urchin interactions would indirectly affect algae; therefore, I did not analyze the behavior or foraging range of sea urchins, nor did I address fishes-urchin attacks. Nevertheless, patchy distribution and foraging behavior of sea urchins were observed in combined treatments.

The mechanism by which sea urchins detect predators is not still clear, but their responses are probably mediated by a combination of conditioning and sensitivity to biochemical cues (Kats \& Dill 1998). For example, Hagen et al. (2002) attributed the defensive behavioral responses of sea urchins to chemical detection of active predators (wolfish and crab): chemical information is released during predatory attacks from conspecifics, or emitted by active predators that have been chemically labelled by their recent diet.

The contribution of omnivory to structuring food webs has been discussed in a theoretical framework (e.g. Polis \& Strong 1996, Persson 1999, Polis 1999), and 
increasing evidence indicates that it may be a powerful force in freshwater systems (e.g. Diehl 1992). However, there is still little experimental evidence to support this, particularly for benthic marine assemblages (reviewed by Menge 2000). As predators, omnivorous fishes may cause individual herbivorous species to alter their behavior and consequently reduce their grazing range, which in turn affects the whole food web. Trophic cascades are affected by flexible behavior in 1 or several levels in both aquatic and terrestrial systems (e.g. Carpenter et al. 1987, Schmitz et al. 1997), indicating that trait-mediated, indirect interactions (TMIIs) may give rise to strong and unpredictable trophic cascades (reviewed by Werner \& Peacor 2003).

TMIIs may have an important but underestimated role in structuring communities (e.g. Bruno et al. 2003, Trussell et al. 2003). Models based only on predation or competition interactions may provide an incomplete, and in some cases misleading, picture of the structure and organization of ecological systems (Bruno et al. 2003). Recent experimental evidence for freshwater (e.g. Turner et al. 2000. Peacor \& Werner 2001) and terrestrial (Beckerman et al. 1997, Schmitz et al. 1997, Schmitz \& Suttle 2001) systems highlights the importance of these mechanisms. Nevertheless, in marine systems, information on this issue is scarce and mainly derived from intertidal communities (Raimondi et al. 2000, Dill et al. 2003, Trussell et al. 2003, but see Siddon \& Witman 2004). For example, Trussell et al. (2003) described trait-mediated effects in the crabsnail-barnacle-algae intertidal food web, in which predator cues reduce the foraging behavior of snails, a response that indirectly benefits barnacles and algae. In a marine subtidal community, Siddon \& Witman (2004) demonstrated that lobsters produce a positive indirect effect on mussels by reducing crab predation through modifying the latter's behavior, thus dampening changes in community structure.

In summary, my results support the concept of TMIIs in subtidal communities, probably caused by the escape response of sea urchins when they detect predatory fishes. Omnivorous fishes may have different direct or indirect effects on lower food levels. On the one hand, they may directly reduce algae by herbivory; on the other hand, they may indirectly mitigate herbivory by urchins, either by reducing sea urchin populations (via trophic cascade), or by restricting the home range and activity of the sea urchins via TMII.

Acknowledgements. I thank Jordi Gonzalez, Gemma Cantos, Raquel Heras, Cristina Linares, David Diaz, Fiona Tomas, Marc Marí, Mikel Zabala and Josep Maria Llenas for field and laboratory assistance, and Enric Ballesteros for his comments and suggestions. This study is part of my PhD thesis, directed by Enric Sala and Mikel Zabala, whose help was essential in designing and writing this paper. Special thanks to Marc Verlaque, who kindly and patiently reviewed, corrected and greatly improved this manuscript. I am also grateful to Antoni Garcia-Rubies and Teresa Alcoverro for their help, especially in the statistical analysis. Special thanks also to 4 anonymous reviewers, who greatly improved this manuscript with appropriate and constructive suggestions and comments. This study was funded by grant MAR1999-0526, and by the Department de Medi Natural of the Generalitat de Catalunya.

\section{LITERATURE CITED}

Anderson MJ (1999) Distinguishing direct from indirect effects of grazers in intertidal estuarine assemblages. J Exp Mar Biol Ecol 234:199-218

Andrew NL (1993) Spatial heterogeneity, sea urchin grazing, and habitat structure on reefs in temperate Australia. Ecology 74:292-302

Andrew NL, Jones GP (1990) Patch formation by herbivorous fish in a temperate Australian kelp forest. Oecologia 85: $57-68$

Ballesteros E (1991) Structure and dynamics of North-Western Mediterranean phytobenthic communities: a conceptual model. In: Ros JD, Prat N (eds) Homage to Ramon Margalef, or, Why there is such pleasure in studying nature? Oecol Aquat 10:223-242

Bayle JT, Valle C, Verdú A (2001) EcoCEN v.1.00: application for managing fish visual counts. Inf Estud COPEMED No. 7: ECOGEN, available at: www.faocopemmed.org

Beckerman AP, Uriarte PM, OJ Schmitz (1997) Experimental evidence for a behaviour-mediated trophic cascade in a trophic food chain. Proc Natl Acad Sci USA 94:10735-10738

Bruno JF, Stachowicz JJ, Bertness MD (2003) Inclusion of facilitation into ecological theory. Trends Ecol Evol 18: 119-125

Carpenter SR, Kitchell JF, Hodgson JR, Cochran PA and 6 others (1987) Regulation of lake primary productivity by food web structure. Ecology 68:1863-1876

Choat JH (1982) Fish feeding and the structure of benthic communities in temperate waters. Annu Rev Ecol Syst 13: 423-449

Crook AC, Long M, Barnes DKA (2000) Quantifying daily migration in the sea urchin Paracentrotus lividus. J Mar Biol Assoc UK 80:177-178

Day E, Branch GM (2002) Effects of sea urchins (Parechinus angulosus) on juveniles and recruits of abalone (Haliotis midae). Ecol Monogr 72:133-149

Dayton PK, Oliver JS (1980) An evaluation of experimental analyses of populations and community patterns in benthic marine environments. In: Tenore KR, Coull BC (eds) Marine benthic dynamics. University of South California Press, Georgetown, SC, p 93-120

Diehl S (1992) Fish predation and benthic community structure: the role of omnivory and habitat complexity. Ecology 73:1646-1661

Dill L, Heithaus M, Walters C (2003) Behaviorally mediated indirect interactions in marine communities and their conservation implications. Ecology 84:1151-1157

Garcia-Rubies A (1999) Effects of fishing on community structure and on selected populations of Mediterranean coastal reef fish. Nat Sicil 23:59-81

Garcia-Rubies A, Zabala M (1990) Effects of total fishing prohibition on the rocky fish assemblages of Medes Islands Marine Reserve (NW Mediterranean). Sci Mar 54:317-328

Hagen NT, Mann KH (1994) Experimental analysis of factors influencing the aggregating behaviour of the green sea urchin Strongylocentrotus droebachiensis. J Exp Mar Biol Ecol 176:107-126 
Hagen NT, Andersen A, Stabell OB (2002) Alarm responses of the green sea urchin, Strongylocentrotus droebachiensis, induced by chemically labelled durophagous predators and simulated acts of predation. Mar Biol 140:365-374

Hairston NG, Smith FE, Slobodkin LB (1960) Community structure, population control, and competition. Am Nat 94: 421-425

Hay ME (1981) Spatial patterns and grazing intensity of a Caribbean barrier reef: herbivory and algal distributions. Aquat Bot 11:97-109

Hay ME (1991) Fish-seaweed interaction on coral reef: effect of herbivorous fishes and adaptations of their prey. In: Sale PF (ed) The ecology of fishes on coral reef. Academic Press, San Diego, CA, p 96-119

Hereu B (2004) The role of trophic interactions between fishes, sea urchins and algae in the Northwestern Mediterranean rocky infralittoral. $\mathrm{PhD}$ thesis, Universitat de Barcelona

Hereu B (2005) Movements pattern of the sea urchin Paracentrotus lividus in the NW Mediterranean. Mar Ecol 26: $54-62$

Hereu B, Linares C, Zabala M, Sala E (2005) The effects of predator abundance and habitat structural complexity on survival of juvenile sea urchins. Mar Biol 146:243-249

Horn MH (1989) Biology of marine herbivorous fishes. Oceanogr Mar Biol Annu Rev 27:167-272

Jones GP, Andrew NL (1990) Herbivory and patch dynamics on rocky reefs in temperate Australasia: the roles of fish and sea urchin. Austr J Ecol 15:505-520

Kats LB, Dill LM (1998) The scent of death: chemosensory assessment of predation risk by prey animals. Ecoscience 5:361-394

Kennelly SJ (1991) Caging experiments to examine the effects of fishes on understorey species in a sublittoral kelp community. J Exp Mar Biol Ecol 147:207-230

Lawrence JM (1975) On the relationship between marine plants and sea urchins. Oceanogr Mar Biol Annu Rev 13:213-286

Lewis SM (1986) The role of fishes on the organization of a Caribbean reef community. Ecol Monogr 56:183-200

Lubchenco J, Gaines SD (1981) A unified approach to marine plant-herbivore interactions. I. Populations and communities. Annu Rev Ecol Syst 12:405-437

McClanahan TR, Sala E (1997) A Mediterranean rocky-bottom ecosystem fisheries model. Ecol Model 104:145-164

McNaughton SJ, Georgiadis JN (1986) Ecology of African grazing and browsing mammals. Annu Rev Ecol Syst 17: 39-65

Menge BA (1995) Indirect effects in marine rocky intertidal interaction webs: patterns and importance. Ecol Monogr 65:21-74

Menge BA (2000) Top-down and bottom-up community regulation in marine rocky intertidal habitats. J Exp Mar Biol Ecol 250:257-289

Oksanen L, Fretwell SD, Arruda J, Niemelä P (1981) Exploitation ecosystems in gradients of primary productivity. Am Nat 118:240-261

Peacor SD, Werner E (2001) The contribution of trait-mediated indirect effects to the net effects of a predator. Proc Natl Acad Sci USA 98:3904-3908

Persson L (1999) Trophic cascades, abiding heterogeneity and the trophic level concept at the end of the road. Oikos 85: 385-397

Pinnegar JK, Polunin NVC (2000) Contributions of stable-isotope data to elucidating food webs of Mediterranean rocky littoral fishes. Oecologia 122:399-409

Polis GA (1999) Why are parts of the world green? Multiple factors control productivity and the distribution of bio- mass. Oikos 86:3-15

Polis GA, Strong DR (1996) Food web complexity and community dynamics. Am Nat 147:813-846

Prince J (1995) Limited effects of the sea urchin Echinometra mathaei (de Blainville) on the recruitment of benthic algae and macroinvertebrates into intertidal rock platforms at Rottnest Island, Western Australia, J Exp Mar Biol Ecol 186:237-258

Raimondi P, Forde S, Delph L, Lively C (2000) Processes structuring communities: evidence for trait-mediated indirect effects through induced polymorphisms. Oikos 91:353-361

Ruitton S, Francour P, Boudouresque CF (2000) Relationship between algae, benthic herbivorous invertebrates and fishes in rocky sublittoral communities of a temperate sea (Mediterranean). Estuar Coast Shelf Sci 50:217-230

Sala E, Ballesteros E (1997) Partitioning of space and food resources by three fish of the genus Diplodus (Sparidae) in a Mediterranean rocky infralittoral ecosystem. Mar Ecol Prog Ser 152:273-283

Sala E, Boudouresque CF (1997) The role of fishes in the organization of a Mediterranean sublittoral community. I. Algal communities. J Exp Mar Biol Ecol 212:25-44

Sala E, Zabala M (1996) Fish predation and the structure of the sea urchin Paracentrotus lividus populations in the NW Mediterranean. Mar Ecol Prog Ser 140:71-81

Sala E, Boudouresque CF, Harmelin-Vivien M (1998) Fishing, trophic cascades, and the structure of algal assemblages: evaluation of an old but untested paradigm. Oikos 82: 425-439

Schmitz OJ, Suttle KB (2001) Effects of top predator species on direct and indirect interactions in a food web. Ecology 82:2072-2081

Schmitz OJ, Beckerman A, O'Brien KM (1997) Behaviorally mediated trophic cascades: effects of predation risk on food web interactions. Ecology 78:1388-1399

Siddon CE, Witman D (2004) Behavioral indirect interactions: multiple predator effects and prey switching in the rocky subtidal. Ecology 85:2938-2954

Tegner MJ, Dayton PK, Edwards PB, Riser KL (1995) Sea urchin cavitation of giant kelp (Macrocystis pyrifera C. Agardh) holdfasts and its effects on kelp mortality across a large California forest. J Exp Mar Biol Ecol 191:83-99

Trussell GC, Ewanchuk PJ, Bertness MD (2003) Trait-mediated effects in rocky intertidal food chains: predator risk cues alter prey feeding rates. Ecology 84:629-640

Turner AM, RJ Bernot, CM Boes (2000) Chemical cues modify species interactions: the ecological consequences of predator avoidance by freshwater snails. Oikos 88: $148-158$

Underwood AJ (1997) Experiments in ecology: their logical design and interpretation using analysis of variance. Cambridge University Press, Cambridge

Verlaque M (1984) Biologie des juvéniles de l'oursin herbivore Paracentrotus lividus (Lamark): séléctivité du broutage et impact de l'espèce sur les communautés de substrat rocheux en Corse (Méditeranée, France). Bot Mar 27:401-424

Verlaque M (1990) Relations entre Sarpa salpa (Linnaeus, 1758) (Téléostéen, Sparidae), les autres poissons broteurs et le phytobenthos algal méditeranéen. Oceanol Acta 13: 373-388

von Ende CN (1993) Repeated-measures analysis: growth and other time-dependent measures. In: Schneider SM, Gurevitch J (eds) Design and analysis of ecological experiments. Chapman \& Hall, New York, p 113-137

Werner E, Peacor S (2003) A review of trait-mediated interactions in ecological communities. Ecology 84:1083-1100

Submitted: January 18, 2005; Accepted: October 25, 2005

Proofs received from author(s): April 11, 2006 